\title{
Factors associated with delay in seeking care by tuberculosis patients
}

\author{
Fatores associados ao atraso na procura por atendimento pelo doente de tuberculose \\ Factores asociados a demoras en la búsqueda de atención del enfermo de tuberculosis
}

\section{Dândara Nayara Azevêdo Dantas', Bertha Cruz Enders', Déborah Raquel Carvalho de Oliveira', Caroline Evelin Nascimento Kluczynic Vieira', Ana Angélica Rêgo de Queiroz", Ricardo Alexandre Arcêncio" \\ ' Universidade Federal do Rio Grande do Norte, Postgraduate Program in Nursing. Natal, Rio Grande do Norte, Brazil. \\ "Universidade de São Paulo, Ribeirão Preto College of Nursing, Nursing Doctoral Interunits Undergraduate Program. Ribeirão Preto, São Paulo, Brazil.}

\section{Dant}

How to cite this article:

Dantas DNA, Enders BC, Oliveira DRC, Vieira CENK, Queiroz AAR, Arcêncio RA. Factors associated with delay in seeking care by tuberculosis patients. Rev Bras Enferm [Internet]. 2018;71(Suppl 1):646-51. [Thematic Issue: Contributions and challenges of nursing practices in collective health] DOI: http://dx.doi.org/10.1590/0034-7167-2016-0680

Submission: 02-05-2017 Approval: 11-18-2017

\begin{abstract}
Objective: To identify social, clinical and behavioral factors of tuberculosis patients that are associated with delay in the search for primary health care. Method: This is a cross-sectional, quantitative study conducted with 56 people on treatment for pulmonary tuberculosis in the city of Natal, in the state of Rio Grande do Norte, Brazil. The data were collected through a structured instrument. The Chi-square and Fisher tests were applied to test the association between independent and dependent variables (search time). A value of $p<0.05$ was set as statistically significant. Results: No social or clinical variables were statistically associated with patient delays in the search for primary health care. Among the behavioral variables, self-medication and the first health service sought had a statistically significant association with the time for seeking care $(p=0.020$, and $p=0.033$, respectively). Conclusion: Selfmedication contributes to the delay in the search for primary health care by tuberculosis patients.
\end{abstract}

Descriptors: Tuberculosis; Delayed Diagnosis; Self Medication; Health Services; Patient Acceptance of Health Care.

\section{RESUMO}

Objetivo: Identificar fatores sociais, clínicos e comportamentais dos doentes de tuberculose que estejam associados ao atraso na procura pelo primeiro atendimento à saúde. Método: Estudo transversal, quantitativo, conduzido com 56 pessoas em tratamento da tuberculose pulmonar em Natal/RN, Brasil. Os dados foram coletados por meio de instrumento estruturado. Aplicaram-se os testes de Qui-quadrado e Fisher para testar a associação entre as variáveis independentes e dependentes (tempo de procura). Fixou-se valor de $p$ $<$ 0,05 como estatisticamente significativo. Resultados: Nenhuma variável social ou clínica se mostrou estatisticamente associada ao atraso do doente na procura pelo primeiro serviço de saúde. Dentre as variáveis comportamentais, a automedicação e o primeiro serviço de saúde procurado apresentaram associação estatística significativa com o tempo de procura ( $p=0,020$ e $p=0,033$, respectivamente). Conclusão: A automedicação contribui para o atraso na procura pelo primeiro atendimento à saúde pelo doente de tuberculose.

Descritores: Tuberculose; Diagnóstico Tardio; Automedicação; Serviços de Saúde; Aceitação pelo Paciente de Cuidados de Saúde.

\section{RESUMEN}

Objetivo: Identificar factores sociales, clínicos y conductuales de enfermos de tuberculosis, asociados a la demora por buscar la primera atención de salud. Método: Estudio transversal, cuantitativo, realizado con 56 personas en tratamiento de tuberculosis pulmonar, en Natal/RN, Brasil. Datos recolectados mediante instrumento estructurado. Se aplicaron los tests de Chi-cuadrado y de Fisher para probar la asociación entre las variables dependientes e independientes (tiempo de búsqueda). Se estableció un valor de $p<0,05$ como estadísticamente significativo. Resultados: Ninguna variable social o clínica mostró asociación estadística a la demora del enfermo en la búsqueda de la primera atención de salud. Entre las variables conductuales, la automedicación y el primer servicio de salud 
buscado presentaron asociación estadísticamente significativa con el tiempo de búsqueda ( $p=0,020$ y $p=0,033$, respectivamente) . Conclusión: La automedicación contribuye a la demora en la búsqueda de la primera atención de salud en el enfermo de tuberculosis. Descriptores: Tuberculosis; Diagnóstico Tardío; Automedicación; Servicios de Salud; Aceptación de la Atención de Salud.

\section{CORRESPONDING AUTHOR Dândara Nayara Azevêdo Dantas E-mail: dandara_dantas@hotmail.com}

\section{INTRODUCTION}

Tuberculosis (TB) is an infectious and contagious disease of global epidemiological impact ${ }^{(1)}$. Although the mortality and prevalence rates declined between 1990 and 2015 by approximately $42 \%$, in the latter year it was considered one of the 10 leading causes of death in the world ${ }^{(1)}$. Brazil followed the decrease in the mortality rate and, in 2015, obtained an index of 2.7 deaths per 100,000 inhabitants among people not infected by the human immunodeficiency virus (HIV). In that year, the incidence of TB was 41 people per 100 thousand inhabitants ${ }^{(1)}$.

This is a collective health problem due not only to the high incidence of the disease but also to the delay in diagnosing it, once the diagnosis and early treatment of TB are essential factors in its control. The importance of these factors is evident as they help reduce morbidity and mortality from the disease, and minimize the risk of contagion ${ }^{(2-3)}$.

In this perspective, the time the user waits from the appearance of the first symptoms to the search for primary healthcare service is a determining factor for the delay of the TB diagnosis. Therefore, a delayed search behavior can be considered a key point that deserves greater intervention, because it implies a delay in diagnosis, and favors a greater spread and worsening of the disease ${ }^{(4)}$.

Regarding this time, studies carried out in Brazil point to variations in the time elapsed between the appearance of symptoms and the search, by TB patients, for primary health care. In the cities of Ribeirão Preto and São José do Rio Preto, in the state of São Paulo, for example, the median time was 15 days $^{(5-6)}$. In the city of Foz do Iguaçu, in the state of Paraná, and in the city of Rio de Janeiro, in the state of Rio de Janeiro, the median was 30 days $^{(4,7)}$.

In the present study, the time to search for care of more than 21 days was considered a delay, because this period is considered to be characteristic of respiratory symptoms ${ }^{(8)}$.

Among the aspects related to the delay in the search for the first health service by the TB patient, the most important are gender, unemployment and $\operatorname{cough}^{(7)}$, as well as satisfactory knowledge about the disease ${ }^{(5)}$. However, it is thought that other variables may be related to delay ${ }^{(4-5,7)}$. It is also emphasized that these studies were carried out in large urban centers of the country.

Given the few studies in Brazil focusing on this complex relationship between the time of TB symptoms and the search for health care services, there is a need to investigate the aspects that may delay this behavior in different regions of the country. Therefore, several factors can undergo analysis models to indicate the ones that contribute the most to this delay, allowing more focused intervention actions. Therefore, we can consider that the investigation of related factors in different contexts may clarify this multiplicity.

Since the time for searching for primary care is an important indicator of health, it is important to develop studies on the subject in order to increase the knowledge about TB patients' behavior in the search for treatment, and care for their health.

\section{OBJECTIVE}

To identify TB patients' social, clinical and behavioral aspects related to the delay in searching for primary health care.

\section{METHOD}

\section{Ethical aspects}

The study was approved by the Research Ethics Committee of the Federal University of Rio Grande do Norte (UFRN), and followed Resolution 196/96 of the National Health Council in force for research involving human beings.

\section{Study design, setting and period}

This is a cross-sectional study of quantitative approach developed in the city of Natal, in the state of Rio Grande do Norte, Brazil, between February and September 2012.

This city is divided into five health districts (North I, North II, West, East, South), having 199 health facilities in the service network of the Unified Health System (SUS), with 52 Basic Units/Health Centers, and two mixed units, which cover an estimated $55.04 \%$ of the population ${ }^{(9)}$. It also has a public hospital, reference in the state in infectious diseases.

\section{Population or sample: inclusion and exclusion criteria}

The population consisted of patients with pulmonary tuberculosis, and was quantified in 2010 by the National Disease Notification System (SINAN), in 304 individuals $^{(10)}$. The sample size was determined by means of a sample calculation for finite populations with a margin of error of 0.10 , and a confidence level of $90 \%$, totaling 56 subjects.

The participants were selected as they were found until they reached the specified sample number. The study included individuals older than 18 years, and who were in the second month of treatment of pulmonary TB at some Municipal Health Unit of Natal. Exclusion criteria were: individuals with pulmonary TB who were admitted in the Brazilian prison system, or who had a diagnosis of mental illness.

\section{Study protocol}

The subjects were recruited by three contributors: two undergraduate nursing students, and one Master student of the Nursing Graduate Program, all of whom were properly 
trained to perform data collection. The patients were identified through the TB registry of the health units, and invited to participate in the study during the monthly consultation with the nurse for treatment follow-up, or through a home visit performed with the community health worker.

Data were collected in interviews using a structured instrument with closed-ended questions containing information on sociodemographic, clinical, and behavioral habits data, and about the search for treatment services. The instrument was formulated by the researchers, and submitted to a pre-test in January 2012 with five people on TB treatment in another city, located in a region near the city of Natal, which were not included in the final sample.

After some adjustments, the questionnaire was sent to two PhD nurses with experience in studies in the area of tuberculosis, for face validation of the instrument; their opinion on the content was also asked. They suggested small changes in terminologies, which were applied.

Variables related to the social profile of the patients were used for the development of the present study, along with clinical variables regarding health status when seeking primary health service, behavioral variables (use of alcohol, smoking, and use of illicit drugs, degree of concern for health, first health service sought, and selfmedication); and the variable related to the time (days) between the perception of the first symptoms and signs of the disease, and the search for the first health service.

It should be noted that all data collected on health status - time of perception of the symptoms and signs of the disease until the search for health care; and patient behavior - were obtained from their self-perception in relation to these variables. No other means were used to gauge such information.

\section{Analysis of results and statistics}

Data were entered into an electronic database, and analyzed through the Statistical Package for the Social Sciences (SPSS), version 15.0. Descriptive statistics were used with frequency and percentage counts for categorical variables; for continuous variables, mean central tendency measures (mean and median) were calculated.

The variables were dichotomized, and the association between the independent variables $(X, Y, Z, K)$ and the time-dependent variable ( $\leq 21$ days or $>21$ days) were tested by the chi-square test of association or Fisher's test, when required. A probability of type I error at $5 \%$ was established as statistically significant.

\section{RESULTS}

The median time elapsed between the perception of the first symptoms and signs of tuberculosis and the search for the first health service was 30 days, with the minimum time being no day and the maximum time of 150 days, with an interquartile range of 14,25 and 82.50 days.

The results of the bivariate analysis show that the social and clinical variables did not present a statistically significant association with time to search for the first healthcare service, as shown in Table 1.

Table 1 - Distribution of social and clinical variables of tuberculosis patients regarding time elapsed for searching for healthcare services, Natal, Rio Grande do Norte, Brazil, 2012

\begin{tabular}{|c|c|c|c|}
\hline Social and clinical variables & $\begin{array}{c}\text { Time } \leq \mathbf{2 1} \text { days } \\
\text { n (\%) }\end{array}$ & $\begin{array}{c}\text { Time }>21 \text { days } \\
\text { n (\%) }\end{array}$ & $\begin{array}{c}p \\
\text { value }\end{array}$ \\
\hline Gender & & & \\
\hline $\begin{array}{l}\text { Female } \\
\text { Male }\end{array}$ & $\begin{array}{l}10(45.5) \\
12(54.5)\end{array}$ & $\begin{array}{l}16(47.1) \\
18(52.9)\end{array}$ & 0.563 \\
\hline $\begin{array}{l}\text { Marital status } \\
\text { With a partner } \\
\text { No partner }\end{array}$ & $\begin{array}{l}10(45.5) \\
12(54.5)\end{array}$ & $\begin{array}{l}13(38.2) \\
21(61.8)\end{array}$ & 0.397 \\
\hline $\begin{array}{l}\text { Race } \\
\text { White } \\
\text { Not white }\end{array}$ & $\begin{array}{l}10(45.5) \\
12(54.5)\end{array}$ & $\begin{array}{l}12(35.3) \\
22(64.7)\end{array}$ & 0.315 \\
\hline $\begin{array}{l}\text { Level of education } \\
\text { No education or incomplete primary education } \\
\text { Complete primary education or more }\end{array}$ & $\begin{array}{c}13(59.1) \\
9(40.9)\end{array}$ & $\begin{array}{l}18(52.9) \\
16(47.1)\end{array}$ & 0.431 \\
\hline $\begin{array}{l}\text { Family income } \\
\text { Less than two minimum wages } \\
\text { More than two minimum wages }\end{array}$ & $\begin{array}{c}16(72.7) \\
6(27.3)\end{array}$ & $\begin{array}{l}23(67.6) \\
11(32.4)\end{array}$ & 0.461 \\
\hline $\begin{array}{l}\text { Cough } \\
\text { Yes } \\
\text { No }\end{array}$ & $\begin{array}{c}19(86.4) \\
3(13.6)\end{array}$ & $\begin{array}{r}32(94.1) \\
2(5.9)\end{array}$ & 0.298 \\
\hline $\begin{array}{l}\text { Sputum } \\
\text { Yes } \\
\text { No }\end{array}$ & $\begin{array}{c}6(27.3) \\
16(72.7)\end{array}$ & $\begin{array}{l}14(41.2) \\
20(58.8)\end{array}$ & 0.220 \\
\hline $\begin{array}{l}\text { Bloody sputum } \\
\text { Yes } \\
\text { No }\end{array}$ & $\begin{array}{c}8(36.4) \\
14(63.6)\end{array}$ & $\begin{array}{l}11(32.4) \\
23(67.6)\end{array}$ & 0.489 \\
\hline $\begin{array}{l}\text { Back pain } \\
\text { Yes } \\
\text { No }\end{array}$ & $\begin{array}{l}11(50.0) \\
11(50.0)\end{array}$ & $\begin{array}{l}17(50.0) \\
17(50.0)\end{array}$ & 0.608 \\
\hline $\begin{array}{l}\text { Weight loss/emaciation } \\
\text { Yes } \\
\text { No }\end{array}$ & $\begin{array}{c}20(90.9) \\
2(9.1)\end{array}$ & $\begin{array}{r}32(94.1) \\
2(5.9)\end{array}$ & 0.515 \\
\hline $\begin{array}{l}\text { Poor appetite } \\
\text { Yes } \\
\text { No }\end{array}$ & $\begin{array}{c}15(68.2) \\
7(31.8)\end{array}$ & $\begin{array}{c}27(79.4) \\
7(20.6)\end{array}$ & 0.262 \\
\hline $\begin{array}{l}\text { Indisposition/tiredness } \\
\text { Yes } \\
\text { No }\end{array}$ & $\begin{array}{c}17(77.3) \\
5(22.7)\end{array}$ & $\begin{array}{c}28(82.4) \\
6(17.6)\end{array}$ & 0.445 \\
\hline $\begin{array}{l}\text { Fever } \\
\text { Yes } \\
\text { No }\end{array}$ & $\begin{array}{c}16(72.7) \\
6(27.3)\end{array}$ & $\begin{array}{c}26(76.5) \\
8(23.5)\end{array}$ & 0.495 \\
\hline
\end{tabular}


Table 2 - Distribution of behavioral variables of tuberculosis patients regarding time elapsed for searching for healthcare services, Natal, Rio Grande do Norte, Brazil, 2012

\begin{tabular}{|c|c|c|c|}
\hline \multirow{2}{*}{ Behavioral variables } & \multicolumn{2}{|c|}{ Time $\leq 21$ days Time $>21$ days } & \multirow{2}{*}{$\begin{array}{c}p \\
\text { value }\end{array}$} \\
\hline & n $(\%)$ & n (\%) & \\
\hline \multicolumn{4}{|l|}{ Frequency of alcohol use } \\
\hline Frequently & $11(50.0)$ & $15(44.1)$ & \multirow{2}{*}{0.437} \\
\hline Hardly ever & $11(50.0)$ & $19(55.9)$ & \\
\hline \multicolumn{4}{|l|}{ Frequency of tobacco use } \\
\hline Frequently & $8(36.4)$ & $15(44.1)$ & \multirow{2}{*}{0.384} \\
\hline Hardly ever & $14(63.6)$ & $19(55.9)$ & \\
\hline \multicolumn{4}{|l|}{ Frequency of illicit drugs use } \\
\hline Frequently & $3(13.6)$ & $4(11.8)$ & \multirow[t]{2}{*}{0.572} \\
\hline Hardly ever & $19(86.4)$ & $30(88.2)$ & \\
\hline \multicolumn{4}{|c|}{ First healthcare service searched } \\
\hline Elective $(\dagger)$ & $6(27.3)$ & 19 (55.9) & \multirow{2}{*}{$0.033^{(* *}$} \\
\hline Urgency(‡) & $16(72.7)$ & $15(44.1)$ & \\
\hline \multicolumn{4}{|l|}{ Concern with health status } \\
\hline Little & $3(13.6)$ & $8(23.5)$ & \multirow[t]{2}{*}{0.290} \\
\hline A lot & $19(86.4)$ & $26(76.5)$ & \\
\hline \multicolumn{4}{|l|}{ Self-medication } \\
\hline Yes & $6(27.3)$ & $20(58.8)$ & \multirow{2}{*}{$0.020^{* *}$} \\
\hline No & $16(72.7)$ & $14(41.2)$ & \\
\hline
\end{tabular}

Note: †Health Unit/Outpatient's; $¥$ Hospital/Emergency Department; **Statistically significant association.

Among the behavioral variables, two showed a statistically significant association: the first place searched for obtaining care $(p=0.033)$ and self-medication behavior $(p=0.029)$ (Table 2).

Thus, it can be observed that tuberculosis individuals who took more than 21 days to search for first health care were those who went to the elective service (55.9\%), and those who were self-medicated $(58.8 \%)$.

\section{DISCUSSION}

The study aimed to identify the social, clinical and behavioral aspects of TB patients related to the delay in the search for the first health care service.

For the participants of the present study, the median time elapsed between the perception of the symptoms and signs of the disease and the search for a health service for diagnosis was 30 days. Although there is no consensus pattern to determine how long the perception of symptoms and the search for the first health service should occur, 30 days can be considered a long time because, within this period, the lack of treatment of bacilliferous people may result in poor prognosis and greater dissemination of the disease ${ }^{(6,11)}$, that is, in individual and collective consequences resulting from the lack of treatment.

According to results from other studies, the time interval between the onset of TB symptoms and signs and the search for health services has varied by an average of 15 to 60 days ${ }^{(4-5,12)}$.
It is important to highlight that, in the present study, there was a maximum time of 150 days for the search of the first health service, whereas in a study carried out in the city of São José do Rio Preto, state of São Paulo, Brazil, the maximum was 365 days ${ }^{(13)}$; and in the city of Foz do Iguaçu, state of Paraná, Brazil, it was 1,095 days $^{(4)}$.

Although social variables, such as gender, were not associated with the time elapsed until the search for the first service, studies show that male individuals are a determinant of health care, being more susceptible to this delay, because in general, they are less concerned about health care when compared to women, including the factor of workload that prevents them from seeking services ${ }^{(14)}$. In addition, they are more strongly associated with the prevalence of alcoholism and drug use ${ }^{(15)}$.

Regarding the factors related to the clinical variables, it is known that the symptoms and signs present in TB subjects may appear to patients as common to other diseases and not so serious, with no clinical complication nor physical impairment; for example, cough ${ }^{(5)}$. Thus, it is thought that the lack of knowledge related to symptoms and signs legitimizes the patients' passivity or gives them an inappropriate direction about what to be done in face of the problem. These conditions may interfere in the search for health care, and potentiate the delay in the diagnosis of the disease ${ }^{(14)}$.

In addition, it is considered that the delay in the search for the first healthcare service by TB patients occurs due to the difficulty of access to primary health services, because patients are rarely able to schedule a consultation in these services within a period of 24 hours $^{(16)}$. In addition, these facilities have daytime hours, delayed appointment and examinations scheduling ${ }^{(17)}$, factors that interfere in the search for these services as a gateway to health care ${ }^{(18)}$.

Thus, symptomatic patients tend to seek more immediate care at emergency services, which reflects an attempt by the users to achieve agility in care. Therefore, it is important to highlight that the immediate search for hospital units can also be explained by the cultural pattern that involves health, and is linked to the patients' view regarding health services, because there is still the idea that primary care services offer little resolubility. Thus, even without having previously sought primary care services, patients seek the tertiary care level ${ }^{(19)}$.

In addition to the type of service to be chosen in the presence of symptoms and signs of TB, self-medication is also related to the delay in seeking the first health service. This occurs because self-medication ends up being an alternative that provides symptoms relief, especially when it comes to nonspecific symptoms ${ }^{(20)}$, but it delays the search for a health service $^{(21)}$ and can mask a pathology or even make it worse ${ }^{(22)}$.

Self-medication is a common practice among TB patients, as can be seen in a study with 403 people treated for TB. This investigation concluded that in the group of patients in hospital care, $39.2 \%$ used self-medication before seeking a health service; in the other group consisting of outpatient patients, $40.3 \%$ also reported self-medication ${ }^{(17)}$.

This great demand for self-medication is explained by a qualitative study developed in Peru, which points out that TB patients tend to assume that the initial symptoms are not serious and 
could therefore be treated with symptomatic drugs purchased in a drug store. Commonly, these people did not seek medical diagnosis until the symptoms were severe or debilitating ${ }^{(23)}$.

Therefore, self-medication becomes a determining factor in the delay in the search for health care. According to a study carried out in Uzbekistan, self-medication with antibiotics is a variable statistically associated with the delay in the search for care and consequent diagnosis of the disease $\mathrm{e}^{(24)}$.

Thus, this population habit for relieving symptoms should be discouraged, given that if the individual has TB, self-medication may extend the time to search for health services; the consequences are: longer time to obtain the diagnosis and begin treatment, worsening of the clinical picture, and need for hospitalization ${ }^{(17)}$.

\section{Study limitation}

The fact that some data were obtained from self-perception may be a limitation of the study because this self-assessment depends on memory. In addition, the use of a small and intentionally selected sample makes it difficult to generalize the data found.

Contributions to the nursing, health or public policy areas

The present study progresses in knowledge by identifying the variables associated with the delay in seeking primary care in the health service. Recognizing that self-medication and the search for elective care favor the longer time to search for TB care is an alert for healthcare professionals, especially those in primary health care, to develop actions aimed at health education, with emphasis on discouraging self-medication, and on the early recognition of the symptoms and signs of this disease.

\section{CONCLUSION}

The delay to search for primary health care by TB patients was related to two behavioral variables: self-medication and the search for elective health services, rather than to clinical and social variables.

It is suggested that self-medication be discouraged by primary care professionals in any health situation; and that institutional, governmental and professional activities be implemented in order to enhance the bond between users and family health units so that the latter can be recognized as a gateway to health care. In addition, it is proposed that investigations be conducted using other sources of information that have the possibility of adding data to those found in the present research.

\section{REFERENCES}

1. World Health Organization. WHO. Global tuberculosis report 2016[Internet]. 2016[cited 2017 Jun 5]. Available from: http://apps. who.int/iris/bitstream/10665/250441/1/9789241565394-eng.pdf

2. Furlan MCR, Silva RLDT, Marcon SS. Factors associated with early and late diagnosis of tuberculosis: a descriptive study. O Braz J Nurs[Internet]. 2014[cited 2016 Aug 24];13(1):62-71. Available from: http://www.objnursing.uff.br/index.php/nursing/article/ download/4364/pdf_97

3. Antunes LB, Tomberg JO, Harter J, Lima LM, Beduhn DAV, Gonzales RIC. Sintomático respiratório de tuberculose na atenção primária: avaliação das ações segundo as recomendações nacionais. Rev Rene [Internet]. 2016 [cited 2016 Dec 20];17(3):409-15. Available from: http://www.periodicos.ufc.br/index.php/rene/article/view/3481/2724

4. Silva-Sobrinho RA, Andrade RLP, Ponce MAZ, Wysocki AD, Brunello ME, Scatena LM, et al. Retardo no diagnóstico da tuberculose em município da tríplice fronteira Brasil, Paraguai e Argentina. Rev Panam Salud Publica[Internet] 2012 [cited 2016 Dec 20];31(6):461-8. Available from: http://www.scielosp.org/pdf/rpsp/v31n6/v31n6a03.pdf

5. Beraldo AA, Arakawa T, Pinto ESG, Andrade RLP, Wysocki AD, Silva-Sobrinho RA, et al. Atraso na busca por serviço de saúde para o diagnóstico da Tuberculose em Ribeirão Preto (SP). Ciênc Saúde Colet[Internet]. 2012 [cited 2016 Dec 20];17(11):3079-86. Available from: http://www.scielosp.org/pdf/csc/v17n11/v17n11a23.pdf

6. Wysocki AD, Ponce MAZ, Scatolin BE, Andrade RL, Vendramini SHF, Ruffino-Neto A, et al. Delay in seeking initial care for tuberculosis diagnosis. Rev Esc Enferm USP[Internet]. 2013 [cited 2016 Dec 20];47(2):440-7. Available from: http://www.scielo. $\mathrm{br} / \mathrm{pdf} /$ reeusp/v47n2/en_24.pdf

7. Machado ACFT, Steffen RE, Oxlade O, Menzies D, Kritski A, Trajman A. Factors associated with delayed diagnosis of pulmonary tuberculosis in the state of Rio de Janeiro, Brazil. J Bras Pneumol[Internet]. 2011 [cited 2016 Dec 20];37(4):512-20. Available from: http://www.scielo.br/pdf/jbpneu/v37n4/en_v37n4a14.pdf

8. Brasil. Ministério da Saúde, Secretaria de Vigilância em Saúde, Departamento de Vigilância Epidemiológica. Manual de recomendações para o controle da tuberculose no Brasil. Brasília: Ministério da Saúde; 2011.

9. Prefeitura Municipal de Natal. Secretaria Municipal de Saúde. Relatório anual de gestão Natal/RN 2015. Natal: Secretaria Municipal de Saúde de Natal; 2016.

10. Brasil. Ministério da Saúde. Sistema de Informação de Agravos e Notificação. Tabulação de dados Tuberculose. Brasília: Ministério da Saúde; 2011.

11. Oliveira LCS, Nogueira JA, Sá LD, Palha PF, Silva CA, Villa TCS. A discursividade do sujeito sobre sentimentos associados ao enfrentamento da tuberculose. Rev Eletr Enf [Internet]. 2015[cited 2016 Dec 20];17(1):12-20. Available from: http://dx.doi. 
org/10.5216/ree.v17i1.24523

12. Maior ML, Guerra RL, Cailleaux-Cezar M, Golub JE, Conde MB. Time from symptom onset to the initiation of pulmonary tuberculosis in a city with a high incidence of the disease. J Bras Pneumol[Internet] 2012 [cited 2016 Dec 20];38(2):202-9 . Available from: http://www.scielo.br/pdf/jbpneu/v38n2/en_v38n2a09.pdf

13. Sasaki NSGMS, Santos MLSG, Vendramini SHF, Ruffino-Netto A, Villa TCS, Chiaravalloti-Neto F. Delays in tuberculosis suspicion and diagnosis and related factors. Rev Bras Epidemiol[Internet]. 2015 [cited 2016 Dec 21];18(4):809-23. Available from: http:// www.scielo.br/pdf/rbepid/v18n4/en_1980-5497-rbepid-18-04-00809.pdf

14. Trigueiro DRSG, Nogueira JA, Sa LD, Monroe AA, Anjos UU, Villa TCS, et al. A influência dos determinantes individuais no retardo do diagnóstico da tuberculose. Texto Contexto Enferm[Internet]. 2014[cited 2016 Dec 20];23(4):1022-31. Available from: http://www.redalyc.org/html/714/71433508025/

15. Cecilio HPM, Molena-Fernandes CA, Mathias TAF, Marcon SS. Perfil das internações e óbitos hospitalares por tuberculose. Acta Paul Enferm[Internet]. 2013[cited 2017 Jun 05];26(3):250-5. Available from: http://www.scielo.br/pdf/ape/v26n3/08.pdf

16. Andrade RLP, Scatolin BE, Wysocki AD, Beraldo AA, Monroe AA, Scatene LM, et al. Tuberculosis diagnosis: primary health care or emergency medical services? Rev Saúde Pública[Internet] 2013 [cited 2016 Dec 20];47(6):1149-58. Available from: http:// www.scielo.br/pdf/rsp/v47n6/en_0034-8910-rsp-47-06-01149.pdf

17. Costa PV, Senna AL, Oliveira LGD, Siqueira RCAG, Figueiredo SP. Demora no diagnóstico da tuberculose pulmonar em cinco municípios da região metropolitana do Rio de Janeiro, Brasil, 2009-2010. Cad Saúde Colet[Internet] 2012 [cited 2016 Dec 20];20(2):195-202. Available from: http://www.cadernos.iesc.ufrj.br/cadernos/images/csc/2012_2/artigos/csc_v20n2_195-202.pdf

18. Mizuhira VF, Gazetta CE, Vendramini SHF, Ponce MAZ, Wysocki AD, Villa TCS. Procura da atenção básica para o diagnóstico da tuberculose. Arq Ciênc Saúde [Internet]. 2015 [cited 2016 Dec 20];22(2):94-98. Available from: http://www.cienciasdasaude. famerp.br/index.php/racs/article/view/150/pdf_34

19. Paula R, Lefevre F, Lefevre AMC, Galesi VMN, Schoeps D. Why do tuberculosis patients look for urgency and emergency unities for diagnosis: a study on social representation. Rev Bras Epidemiol[Internet]. 2014[cited 2017 Jun 05];17(3):600-14. Available from: http://www.scielo.br/pdf/rbepid/v17n3/1415-790X-rbepid-17-03-00600.pdf

20. Teixeira MDS. Antibioticoterapia: visão do paciente quanto aos riscos da automedicação, levantamento de dados em uma farmácia de bairro no Município de Araranguá, SC [TCC]. Criciúma (SC): Universidade do Extremo Sul Catarinense; 2012.

21. Souza KMJ, Villa TCS, Assolini FEP, Beraldo AA, França UM, Protti ST, et al. Delay in the diagnosis of tuberculosis in prisons: the experience of incarcerated patients. Texto Contexto Enferm[Internet] 2012 [cited 2014 Aug 26];21(1):17-2. Available from: http:// www.scielo.br/pdf/tce/v21n1/en_a02v21n1.pdf

22. Telles Filho PCP, Almeida AGP, Pinheiro MLP. Automedicação em idosos: um problema de saúde pública. Rev Enferm UERJ[Internet] 2013 [cited 2016 Dec 20];21(2):197-201. Available from: http://www.facenf.uerj.br/revenfermuerj.html

23. Paz-Soldan VA, Alban RE, Jones CD, Powell AR, Oberthelman RA. Patient reported delays in seeking treatment for tuberculosis among adult and pediatric TB patients and TB patients co-infected with HIV in Lima, Peru: a qualitative study. Front Public Health[Internet] 2014 [cited 2015 Jan 15];2:1-9. Available from: http://www.ncbi.nlm.nih.gov/pmc/articles/PMC4273630/pdf/ fpubh-02-00281.pdf

24. Belkina TV, Khojiev DS, Tillyashaykhov MN, Tigay ZN, Kudenov MU, Tebbens JD, et al. Delay in the diagnosis and treatment of pulmonary tuberculosis in Uzbekistan: a cross-sectional study. BCM Infect Dis[Internet] 2014 [cited 2015 Jan 27];14:1-8. Available from: http://www.ncbi.nlm.nih.gov/pmc/articles/PMC4248454/pdf/12879_2014_Article_624.pdf 